\title{
Research Regarding Wheat (Triticum aestivum L.) Resistance to Tilletia caries (DC.) Tul. Infection
}

\author{
Andreea-Mihaela BALAU*, Eugen ULEA \\ University of Agricultural Sciences and Veterinary Medicine of Iasi, Mihail Sadoveanu Alley, no. \\ 3, 700490 Iasi, România. \\ * corresponding author: balau_andreea@yahoo.com
}

Bulletin USAMV series Agriculture 72(1)/2015

Print ISSN 1843-5246; Electronic ISSN 1843-5386

DOI 10.15835/buasvmcn-agr: 10426

\begin{abstract}
Common bunt caused by species of Tilletia genus presents an important and constantly increasing cause from an economically point of view and this because of major climate change in recent years that have contributed to record high production losses, sometimes even with a technology culture applied correctly. During 2011-2013 period, at the Ezareni Farm from the University of Agricultural Sciences and Veterinary Medicine there were tested 24 domestic and foreign wheat varieties grown under non-irrigated and artificially infected conditions with Tilletia caries (DC.) Tul . pathogen. The wheat caryopses artificially infected with fungus teliospores were sown in a randomized block type experiences in 4 repetitions. During the growing season there have been made constant observations in order to determine the morphological and biometric characteristics of wheat varieties under study. Considering the climatic conditions, based on observations that were made during of the two-year study, the 24 varieties showed a high variability resistance to Tilletia caries (DC.) Tul. pathogen attack. Following artificial infection of 24 wheat varieties there were identified 13 resistant varieties with values of the attack spikes smaller than 5\%, 6 tolerant varieties with a disease frequency between 5-10\% and two susceptible varieties with frequency of attacked ears upwards of $15 \%$.
\end{abstract}

Keywords: resistance, Tilletia caries, Triticum aestivum .

\section{INTRODUCTION}

Many researchers have studied the common bunt and they also were concerned about the reaction of different species and cultivars of wheat (Triticum vulgare and Triticum durum), winter wheat and spring wheat, to the populations and the races of Tilletia indicating new sources of resistance to certain areas (Dumalasova and Bartos, 2007).

Until now resistant wheat cultivars were obtained that are successfully controlling bunt but the emergence of new virulent races of bunt populations, this resistance may decrease, so it is necessary to identify new sources of resistance to this pathogen (Wilcoxson, and Saari, 1996).
Wheat varieties cultivated in our country have differentiated behavior to diseases especially in the context of climate change (Man, 2012). Acording to Fraga and Saulescu (2008) genetic resistance is the most convenient way of controlling the disease, as it reduces both costs and environmental impact. However, bunt has been known for its high ability to overcome resistance by new, more aggressive races, prompting continuous search for genetic diversity of resistance.

For this reason, a permanent research is required regarding the behavior of wheat to the pathogen attack. The purpose of this paper is the study of wheat varieties behavior to the attack of the Tilletia caries (DC.) Tul. fungus in order to 
identify sources of germoplasm with resistance to this pathogen attack.

\section{MATERIALS AND METHODS}

During the years 2011-2013, at the Ezareni Farm from the University of Agricultural Sciences and Veterinary Medicine there were tested 24 domestic and foreign wheat varieties grown under non-irrigated and artificially infected conditions with Tilletia caries (DC) Tul . pathogen.

For the artificial infection with common bunt were used wheat kernels infected with Tilletia caries (DC.) Tul. Artificial infection with common bunt was realized according to a protocol by Dumalasova and Bartos (2010). In this purpose $0.1 \mathrm{~g}$ of Tilletia caries (DC.) Tul. teliospores was applied to 250 seeds of wheat.

The artificial infected wheat kernels with teliospores of the fungus were planted in a randomized block experiments with 4 repetitions. Permanent observations were made during the growing season in order to determine the morphological and biometric characteristics of studied wheat varieties.

\section{RESULTS AND DISCUSSION}

Results obtained by Dumitras and Bontea (1991) demonstrate that in case of the attack with Tilletia sp. to the cereal crops species there is a series of morphological changes on plant development such as reducing the number of leaves, shortening strains and changing the number of tillers.

Comparing the obtained data in the two years of experimentation regarding Tilletia caries (DC.) Tul. attack frequency of the 24 wheat varieties resulted that in the year of 2013 the frequency of

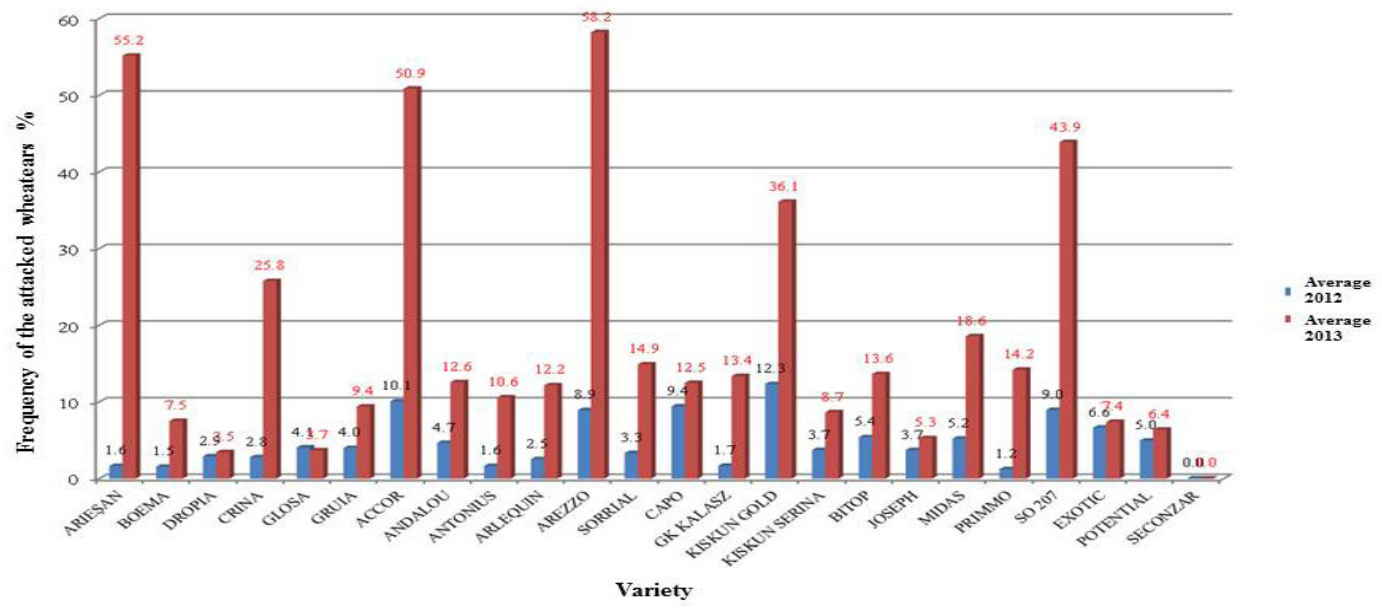

Fig. 1. Frequency of Tilletia caries attack (DC.) Tul. in the two years of experimentation

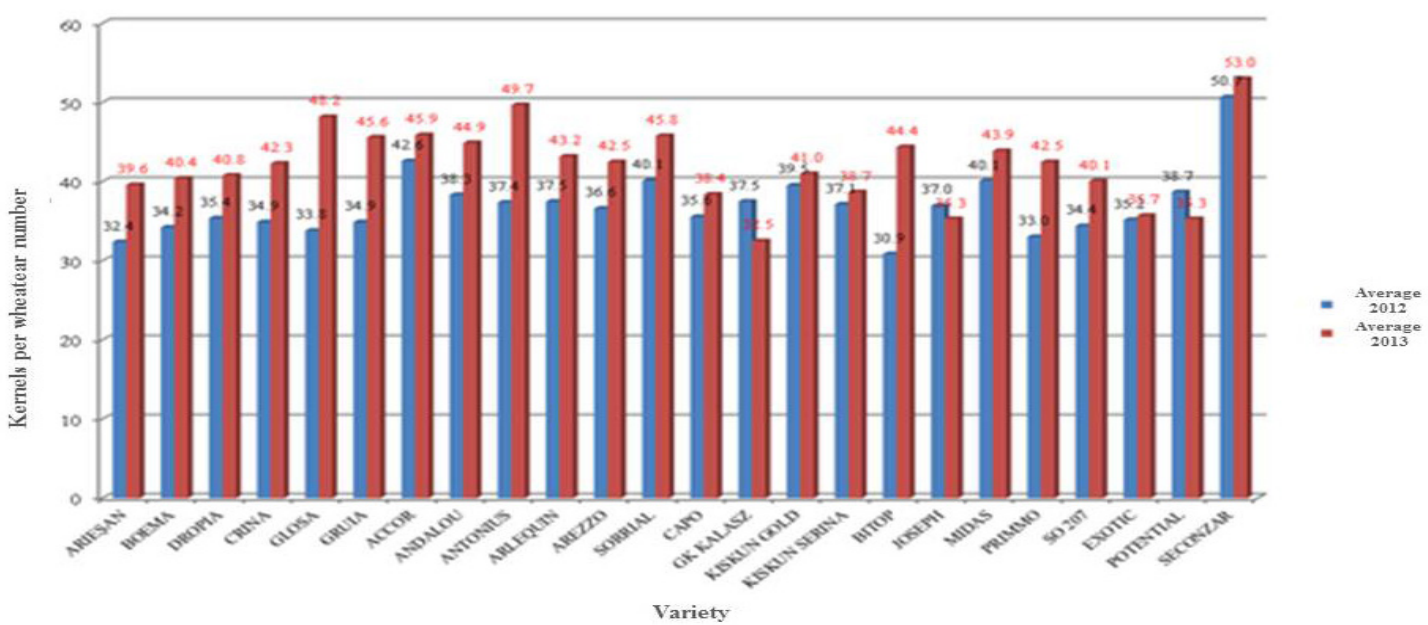

Fig. 2. Influence of Tilletia caries attack (DC.) Tul. on the number of kernels during the two years of experimentation 


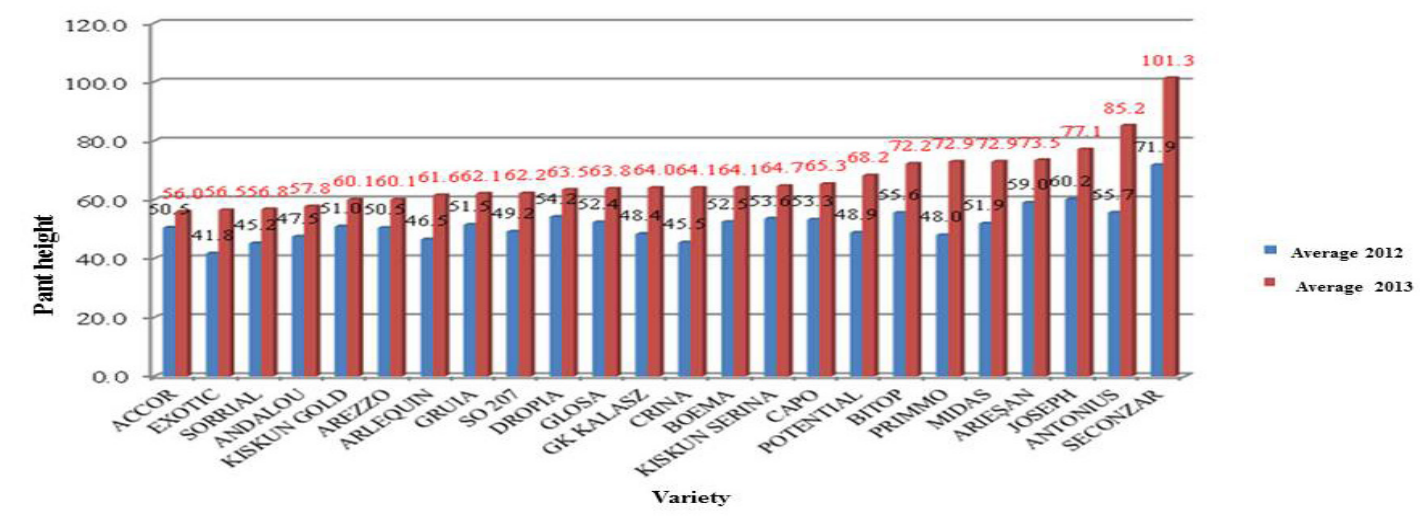

Fig. 3. Influence of Tilletia caries attack (DC.) Tul. on plant height in the two years of experimentation

Tab.1. Influence of Tilletia caries attack (DC.) Tul. on the number of tillers in the agriculture year of 2012-2013

\begin{tabular}{|c|c|c|c|c|c|}
\hline No & Cultivar & Average & $\begin{array}{l}\% \text { in regard } \\
\text { to the control }\end{array}$ & Diferece & Signfication \\
\hline -1- & $-2-$ & $-3-$ & $-4-$ & $-5-$ & -6 \\
\hline 1. & SECONZAR & 5.03 & 119.48 & 0.82 & $\mathrm{xx}$ \\
\hline 2. & ARLEQUIN & 4.30 & 102.24 & 0.09 & - \\
\hline 3. & SORRIAL & 4.3 & 102.24 & 0.09 & - \\
\hline 4. & $\begin{array}{c}\text { CONTROL (experience } \\
\text { average ) }\end{array}$ & 4.21 & 100 & 0 & - \\
\hline 5. & CRINA & 4.2 & 99.86 & -0.01 & - \\
\hline 6. & MIDAS & 4.18 & 99.27 & -0.03 & - \\
\hline 7. & KISKUN SERINA & 4.18 & 99.27 & -0.03 & - \\
\hline 8. & ACCOR & 4.15 & 98.67 & -0.06 & - \\
\hline 9. & ANDALOU & 4.15 & 98.67 & -0.06 & - \\
\hline 10. & GK KALASZ & 4.15 & 98.67 & -0.06 & - \\
\hline 11. & AREZZO & 4.15 & 98.67 & -0.06 & - \\
\hline 12. & JOSEPH & 4.13 & 98.08 & -0.08 & - \\
\hline 13. & SO 207 & 4.05 & 96.29 & -0.16 & - \\
\hline 14. & POTENTIAL & 4.05 & 96.29 & -0.16 & - \\
\hline 15. & BOEMA & 4 & 95.11 & -0.21 & - \\
\hline 16. & BITOP & 4 & 95.11 & -0.21 & - \\
\hline 17. & САРО & 3.98 & 94.64 & -0.23 & - \\
\hline 18. & PRIMMO & 3.98 & 94.51 & -0.23 & - \\
\hline 19. & ANTONIUS & 3.9 & 92.73 & -0.31 & - \\
\hline 20. & KISKUN GOLD & 3.9 & 92.73 & -0.31 & - \\
\hline 21. & ARIESAN & 3.83 & 90.94 & -0.38 & - \\
\hline 22. & EXOTIC & 3.8 & 90.35 & -0.41 & - \\
\hline 23. & GRUIA & 3.68 & 87.38 & -0.53 & - \\
\hline 24. & DROPIA & 3.68 & 87.38 & -0.53 & - \\
\hline 25. & GLOSA & 3.6 & 85.59 & $-0,61$ & o \\
\hline & DL $5 \%=0.57$ & \multicolumn{2}{|c|}{ DL $1 \%=0.77$} & \multicolumn{2}{|c|}{ Dl $0.1 \%=1.03$} \\
\hline
\end{tabular}


attacked wheat ears was higher than in the year 2012.

The highest values, $25.8 \%$ to $55.2 \%$ of the infected wheat ears were recorded in the 'Ariesan', 'Crina', 'Accor', 'Arezzo', 'Kiskun Gold' and 'SO 207' varieties, in the year of 2013 in regard to the year 2012 in which the same cultivars had a frequency of the disease between $1.6 \%$ and $9 \%$.

This fact can be explained by the greater amount of precipitation that was recorded in the year of 2013 compared to the year of 2012 in which droughts were recorded (Fig. 1).

Regarding the number of kernels per wheat ear, it can observed that in year of 2013 the average number of the infected kernels was higher in the 24 species studied compared to that recorded in the year of 2012. The highest differences in the kernels number per wheat ear were observed in the 'Glosa' variety which in the year of 2012 had an average of the infected kernels per ear by $33.8 \%$, and in the year of 2013 had a value of kernels per wheat ear by $48.2 \%$. Also the highest differences of the infected kernel were observed in the 'Gruia', 'Glosa', 'Arlequin', 'Bitop' and 'Primo' varieties (Fig. 2).

During the two years of the experimentation plant height varied being influenced by the climatic conditions and the infection with Tilletia caries (DC.) Tul. Due to the favourable climatic conditions in the agricultural year of 2012-2013 the height of the cultivated plants in this year was higher than the height of the cultivated plants in the agricultural year of 2011-2012. The differences between the average from the two years of experimentation have ranged between 9.8\% and 34.7\% in 'Accor' and 'Antonius' variety. Also higher differences were recorded in 'Seconzar' variety by $34,2 \%$ (Fig. 3).

According to Huszar (1993) a greatest reduction of plant height was due to Tilletia caries (DC.) Tul. attack, plant height was reduced by $23 \%$ while with $T$. leavis it was reduced by $28 \%$. Also a significant reduction of ear length occurred only in one variety attacked by Tilletia caries (DC.) Tul.

Analyzing data obtained from artificial infection Arsene et al. (2013) observed that the attack of Tilletia caries (DC.) Tul. had a low influence on the wheat tiller number on the 24 studied species. Regarding the number of the analyzed wheat tiller in the two years of the research there also is a positive evolution of the wheat tiller in year of 2012-2013, except on the 'Arlequin' and 'SO 207' varieties, wich in the agricultural year of 2011-2012 had higher values of the wheat tiller analyzed by $4.4 \%$ and $4.5 \%$ in regarding to $4.3 \%$ respectively $4.1 \%$, obtained values in the agricultural year of 2012-2013.

Compared to the control (average experience) significant distinctive positive differences were observed only in the 'Seconzar' variety and significant negative differences were observed only in the 'Glosa' variety, the other varieties recorded insignificant differences (Tab.1).

The highest differences of the wheat tiller were observed in 'Joseph' and 'Seconzar' varieties which occurred in the year of 2012-2013 differences of $29.9 \%$ and $25.5 \%$ in regard to the agricultural year of 2011-2012. The range of values of the differences of the two areas was in the range of $0 \%$ to $29.9 \%$.

Current varieties of Triticum aestivum $\mathrm{L}$. grown in Europe have been identified as highly susceptible to bunt (Tilletia tritici and Tilletia laevis). But there were also identified genotypes with resistance in some varieties (Dumalasovaá and Bartos, 2006; Wachter et al., 2007). The results obtained by Cota (2009) after the artificial infection with common bunt spores in the 10 populations analyzed have shown that there are significant differences between the tested populations as regards the resistance to common bunt.

\section{CONCLUSION}

Regarding to the climatic condition and based on the observations that were made in the two years of the study a high resistance variability of the 24 varieties to the attack Tilletia caries (DC.) Tul. pathogen was observed.

Concering the morphology characters observed in the agricultural year of 2012-2013 the recorded values were higher in most studied varieties in regard to the agricultural year of 20112012, those characters were mainly influenced by the climatic conditions of the two years of experimentation and by their infestation with Tilletia caries (DC.) Tul.

In the agricultural year of 2011-2012 the frequency values of the infected wheat ears did not exceed $13 \%$, the highest value was recorded 
in 'Kiskun Gold' variety with a frequency of the infected wheat ears by $12.3 \%$.

The frequency of the infected wheat ears recorded in the agricultural year of 2012-2013 values between $0 \%$ in 'Seconzar' variety and maximum value by $58.2 \%$ in Arezzo variety.

Compared to the first agricultural study year of 2012-2013 on attacked plants by the Tilletia caries fungus the number of the wheat tiller increased along with the frequency of the infected wheat ears with values within $29.8 \%$.

The range of the recorded values regarding the number of the wheat kernels per wheat ear, was from $33.3 \%$ to $53.0 \%$ in the agricultural year of 2012-2013, higher values compared to the results achieved in the noninfected variants which have ranged values between $29.9 \%$ to $51.9 \%$ wheat kernels per wheat ear.

Acknowledgments. This paper was published under the frame of European Social Fund, Human Resources Development Operational Programme 2007-2013, projectno. POSDRU/159/1.5/S/132765.

\section{REFERENCES}

1. Arsene CI, Balau AM, Ulea E (2013). The evaluation of some wheat varieties resistance to infection with pathogen Tilletia caries (D.C.) Tul. Lucrari stiintifice. Seria Horticultura. 56(1): 425-430.
2. Cota LC, Botez C, Grigoras MA, Curticiu D (2009). Screening for resistance to artificial infection by common bunt (Tilletia caries and Tilletia foetida) in F2 populations of wheat (Triticum aestivum L.), Bull. Univ. Agric. Sci. Vet. Med. (USAMV) 66:24-31.

3. Dumalasova V, Bartos P (2007). Reaction of winter wheat cultivars to common bunt, Tilletia tritici (Bjerk.) Wint. and T. laevis Kühn. Plant Protect. Sci. 43: 138-141.

4. Dumalasova V, Bartos P (2010). Reaction of Wheat, Alternative Wheat and Triticale Cultivars to Common Bunt Czech J. Genet. Plant Breed. 46(1): 14-20.

5. Dumitras L, Bontea V (1991). Speciile de Tilletia din Romania: taxonomie, ultrastructură, biologie, combatere. Editura Academiei Române.

6. Huszar J (1993). Wheat reaction to Tilletia species and biological efficiency of chemical seed dressing to control Tilletia laevis Kuhn and Blumeria graminis Speer. Ochrana Rostlin. 29(1): 61-68.

7. Man S, Muste S, Paucean A, Pop A (2012). The Behavior of Some Autumn Wheat Varieties in the Conditions of the Transilvania. Central Area Bulletin UASVM Agriculture. 69(2): 281-289.

8. Wachter R, Waldow F, Muller KJ, Spieß H, Heyden B, Furth U, Frahm J, Weng W, Miedaner T, Stephan D, Koch E (2007). Resistance of winter wheat varieties and breeding lines against common bunt (Tilletia tritici) and dwarf bunt (T. controversa), Nachrichtenbl. Deut. Pflanzenschutzd. 59(2):30-39.

9. Wilcoxson RD, Saari EE (1996). Bunt and Smut Diseases of Wheat: Concepts and Methods of Disease Management. Mexico. D.F.: CIMMYT: 26-32. 